\title{
IMPEACHMENT OF ONE'S OWN WITNESS- NEW DEVELOPMENTS
}

\author{
MASON LADD*
}

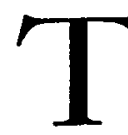

THERE is a need today for a critical examination of many of the rules of evidence, with a view to their reformation. Here and there a forward-looking judge or a courageous court makes a step in advance; but the slow process of judicial reform is inadequate and a resort to legislation is essential. Among the antiquated rules which have been condemned by judges and lawyers is that which in general terms prevents a party from impeaching his own witnesses. More specifically stated, it prevents attack upon a party's witness by evidence tending to show (I) bad character to discredit his general truth and veracity, (2) previous favorable statements inconsistent with the injurious testimony given in the trial to expose the witness' capacity to err and to neutralize the destructive testimony, (3) interest, corruption and bias to establish motive of the witness to testify against the party calling him. Does this rule deserve complete destruction? If so, why has it persisted? If not, should it be preserved unchanged, or should it be modified? If the legislature should act, what action should it take?

\section{ORIGIN AND HISTORY}

The origin of the rule that a party cannot impeach his own witness is not known with certainty. It is commonly believed to have its root in trial by compurgation. This mode of trial was in vogue during the Middle Ages both on the continent and in England, where it became known as trial by wager of law. ${ }^{2}$ A party, by taking oath, could establish his plea of defense if compurgators swore that they believed he spoke the truth. ${ }^{3}$ As the compurgators testified only to the verity of the party's oath, they were little more than character witnesses. They were selected by the party himself from among his immediate kinsmen in early times and later

* Professor of Law, Iowa Law School. For their very kind and valuable assistance, the writer is obliged to Professors Edmund M. Morgan and John MacArthur Maguire, Harvard Law School.

I 2 Wigmore, Evidence $\S 896$ (2d ed. I923); Crago v. State, 28 Wyo. 2I5, 202 Pac. Iog9 (I922).

= Thayer, Preliminary Treatise $24-34,69$ (I898).

3 Id. at 25; Moschzisker, The Fistoric Origin of Trial by Jury, 7o U. of Pa. L. Rev. I, 73, I59, at 80-83 (I92I-22). 
from among his relatives, neighbors, and friends. With such wide range for selection of his oath-helpers, no thought occurred that the party could impeach them. ${ }^{4}$ Thus trial by compurgation set a pattern from which it is possible that the impeachment rule might have developed. The proximity between these two systems of trial is some support for this view. While it was not until the Fifteenth Century that witnesses in the modern sense were used in jury trials, trial by wager of law still existed as a competing institution with the jury. ${ }^{5}$ It may be seriously questioned whether the idea that a party cannot impeach his own witness came from either the system of compurgation or from the decisory oath under the Roman law, where the party who tendered oath became bound by the oath of his adversary. Moreover, it is significant that none of the earlier cases mention compurgation or the decisory oath as the origin of the rule. Furthermore, the first cases stating the rule appear approximately a century after trial by compurgation was abandoned in England. While the impeachment rule is consistent with the practice of trial upon oath, there was no logical reason for the modern mode of litigation to adopt the practice because of the great differences between the two systems of trial. Jury trial as it ultimately developed called for actual testimony as to facts which necessarily precluded the free choice of witnesses. This distinction, together with the fact that the early cases make no mention whatever of the early practice, indicate that any influence by way of compurgation operated indirectly and without deliberation.

A more probable origin of the rule can be found in the transition from the inquisitorial method of trial as it gradually emerged into an adversary system. Jury trial in the modern sense was the outgrowth of the institution of trial by inquisition in which there was no place for the rule that a party could not impeach his own witnesses. Trial by inquest was brought into England at the time of the Norman invasion. It became the parent of the modern jury. ${ }^{6}$ Among the first acts of William the Conqueror was the taking of a census of the people, lands, and conditions which was

42 Wigmore, op. cit. supra note $\mathrm{x}$, at $\S 896$.

$s I d$. at $\S 575$. The defendant could refuse trial by jury in actions of detinue and debt and be tried upon his oath with oath-helpers, during the ${ }_{15}$ th century. Thayer, op. cit. supra note 2 , at $x 7-24,30-3 I$.

${ }^{6}$ Thayer, op. cit. supra note 2, at 7. Whether the jury in England is of Briton or Norman origin or a merger of both, is a matter much discussed by the historians. The Normans, however, gave it a definite place in their system of administering justice among the conquered people. From this time it expanded gradually into an authoritatively recognized method of trial. For conflicting theories and the authorities see Moschzisker, The Historic Origin of Trial by Jury, 7o U. of Pa. L. Rev. I-I3 (I92X). 
recorded in the "Doomsday Book." The method of obtaining the information for this record was through the verdicts of inquest sworn to by selected persons of the neighborhood. Later Henry II at the Council of Nobles held in Clarendon in II66, established a procedure, later known as novel disseisin, to determine questions of seisin and disseisin of land. Out of this procedure the system of inquisitorial trial became common throughout England, extending to all matters of dispute in both civil and criminal causes. This institution soon was accepted as a substitute for earlier modes of trial by ordeal and by battle, and challenged the system of compurgation. The jurors, or recognitors as they were first called, were selected from those in the community who knew, of their own personal knowledge, the facts in dispute. The recognitors, usually twelve in number, heard no evidence but proceeded to determine the cause by comparing their own previous information upon the facts. Later deed-witnesses and transaction-witnesses were used in connection with jury trial. At first they served as jurors themselves and when used in connection with the inquisitorial jury, they did not testify but joined the jurors in their deliberation, giving information to them. Later other witnesses were permitted to give testimony before the inquisitors who acted upon both their personal knowledge and the information gained from the witnesses in rendering a decision. This use of outside testimony was regarded as a radical innovation upon the former method of trial. The ordinary witness could not be compelled to appear and was in fact discouraged in doing so. There was a strong policy against fomenting litigation and the voluntary witness was regarded as a meddler, and might become charged with maintenance. ${ }^{7}$ While voluntary witnesses could be presented to the jury, it was not until the time of Elizabeth that a party could compel the attendance of witnesses in civil cases ${ }^{8}$ and the defendant in criminal cases did not have this right until the last of the Seventeenth Century.9 It was by a gradual process that the system of litigation shifted from an inquisitorial to an adversary character. Even as late as Bushell's case, in 1670 , as stated by Chief Justice Vaughan, the jurors were permitted to rely upon their own information to nullify any testimony given in court. ${ }^{x 0}$ In this latter stage, the jurors were both judges of evidence as well as witnesses

${ }_{7} 4$ Wigmore, op. cit. supra note $x$, at $\$ 2 \mathrm{rgo}$.

${ }^{8}$ Compulsory attendance of witnesses in civil cases was authorized in 1562.5 Eliz. c. 9, $\S$ I2.

9 Twyn's Trial, 6 How. St. Tr. 5r3, 516 (I663); Turner's Trial, 6 How. St. Tr. 565, 570 (1663); Reading's Trial, 7 How. St. Tr. 259, 278 (1679). See I Wigmore, op. cit. supra note I, at $\$ 575$.

s0 6 How. St. Tr. 999 (I670). 
and by gradual process, the system evolved whereby they became solely judges of the evidence apart from any knowledge of their own. It was not until the case of Rex v. Hutton, ${ }^{\text {II }}$ in which Lord Ellenborough declared that a verdict should not be sustained when based upon the jurors' own knowledge rather than evidence produced before them, that there was a clear statement against the system of trial upon personal knowledge of the jurors.

During the period of the inquisitorial system of trial the concept of a witness as a witness of the party did not distinctly emerge. Until there were witnesses in the modern sense, there could be no reason for the idea that a party was bound by his witness or that he could not impeach him. Even then in civil cases, although it became common for parties to produce witnesses during the Fifteenth and Sixteenth Centuries, the cases do not show any statement of the impeachment rule. During this time there was still no occasion for the rule in criminal trials as the accused was not allowed to have any witnesses during the Sixteenth Century.2 By the middle of the Seventeenth Century the use of witnesses for the accused became common ${ }^{13}$ but it was not until 1695 that he could have them testify under oath even in prosecutions for treason. Furthermore, it was not until that year that the accused had the right of counsel in trial for treason and in trials for felony, not until I836..4 But for the most of this period the idea still persisted that a criminal prosecution was not an adversary proceeding. ${ }^{15}$ As the change from the inquisitorial to the adversary system came in criminal cases, we first find the courts declaring that the accused can not impeach his own witnesses. The rule was extended to civil cases and then extended to the prosecution. It conforms to the ancient idea in connection with compurgation, although this procedure had but little relationship to the new mode of trying facts. It naturally fits into the emerging adversary theory of litigation. It became a part of the law without being subjected to close scrutiny as the earlier cases did no more than state the rule. In the Eighteenth and Nineteenth Centuries when the courts began to feel the necessity of justifying accepted rules upon rational grounds, they endeavored to lend respectability to the doctrine and to place limits upon its application.

${ }^{\text {II }} 4$ Maule \& S. 532 (r816).

x2 Throckmorton's Trial, I How. St. Tr. 869, 885 (1554); Udall's Trial, I How. St. Tr. I27I, I280, I304 (I590).

${ }_{3}$ Faulconer's Trial, 5 How. St. Tr. 323, 357 (1653); Hawkins' Trial, 6 How. St. Tr. 92 I 933 (1669).

14 I Wigmore, op. cit. supra note $x$, at $\$ \$ 575,2190$.

${ }^{25}$ Plunket's Trial, 8 How. St. Tr. 447,496 (r68r). 
The two criminal cases in which the rule makes its first reported appearance were decided in I68I, approximately a century after wager of law had dropped into disuse. In Fitzharris' Trial, the accused was informed that he should not disparage his own witnesses and that he could not attempt to obtain a self-contradiction of an unwilling witness. ${ }^{16}$ In Coolidge's Trial, Lord Chief Justice North said:

Look you Mr. Coolidge, I will tell you something for law and to set you right. Whatsoever witnesses you call, you call them as witnesses to testify the truth for you; if you ask them any questions you must take what they have said as true, .... let him answer you if he will but you must not afterwards go to disprove him.17

The earliest civil case upon the subject is apparently Adams v. Arnold, wherein Holt, C.J., "would not suffer the plaintiff to discredit a witness of his own calling, he having testified against him." ${ }^{18}$ In the latter part of the Seventeenth Century, the rule was given further impetus by its use in the trial of Warren Hastings, ${ }^{19}$ in which the prosecution was denied the right to examine a witness produced by it as to prior declarations inconsistent with the answer of the witness. In Rex v. Oldroyd $d^{20}$ a new angle of the question arose when the judge examined a witness whom the prosecution expressed unwillingness to call as she was suspected of being an accomplice. The judge, observing her testimony to favor the accused, had her deposition before the coroner read for the purpose of affecting her credit. When presented for the opinion of the judges it was held proper that the judge admit the contradictory deposition, and Lord Ellenborough and Mansfield, C. J., thought the prosecution had the same right. ${ }^{25}$ In Ewer v. $A m b r o s e^{22}$ it was held error to admit a contradictory statement as substantive evidence. Judges Bayley and Holroyd thought it should not be admitted to discredit the defendant's own witness, but Judge Littledale considered it unnecessary to decide the question. In the leading case of Wright v. Beckett ${ }^{23}$ the plaintiff was allowed to show that his witness who

168 How. St. Tr. 223, 369, 373 (r68r). ${ }_{77} 8$ How. St. Tr. 549, 636 (I681).

${ }^{18}$ I2 Mod. 375, 90 Eng. Rep. 1064 (1700).

${ }^{\prime}$ Warren Hastings' Trial, Lords' Journal, Feb. 9, April 10, 3I Parl. Hist. 369 (I 788). See 2 Wigmore, op. cit. stupra note $\mathrm{r}$, at $\$ \S 896(5), 905 \mathrm{n}$. I.

${ }^{20}$ Russ. \& Ry. 88 (I803).

${ }^{2 x}$ In accord with this view, see State v. Slack, 69 Vt. 486, 38 Atl. 31 I (I897); Litsinger v. U.S., 44 F. (2d) 45 (C.C.A. 7 th I930); Morris v. State, 100 Fla. 850, 130 So. 582 (1930); Carle v. People, 200 Ill. 494, 66 N.E. 32 (I902); People v. Rotello, 339 IIl. 448, I7 I N.E. 540 (1930); but of. People v. Krejewsky, 332 Ill. I20, I63 N.E. 438 (1928).

$=3$ B. \& C. 746 ( 1825$)$.

${ }^{23}$ I Moo. \& Rob. 4I4, 418 ( $\left.x 834\right)$. Lord Denman held similarly in Dunn v. Aslett, 2 Moo. \& Rob. I22 (1838). 
gave adverse testimony had related the facts differently to his attorney before trial. When the point was later argued before Denman, L.C.J., and Bolland, B., opposite views were expressed. Lord Denman gave an able opinion in support of the admission of the impeachment testimony, but Baron Bolland held against it, regarding Rex v. Oldroyd ${ }^{24}$ not in point, and considering Ewer $v$. Ambrose $e^{25}$ as settled precedent. The English courts in later cases uniformly rejected the views of Lord Denman. ${ }^{26}$ Baron Parke, in Holdsworth v. Mayor of Dartmouth, ${ }^{27}$ stated that he had never doubted the opinion of Baron Bolland if the fact sought to be impeached were raised in examination in chief. Justices Erskine, ${ }^{28}$ Patterson, ${ }^{29}$ Wightman $^{30}$ and Dr. Lushington ${ }^{3 x}$ in different cases expressly rejected all efforts of a party to impeach his own witness. The last development before the English Common Law Procedure $\mathrm{Act}^{32}$ is found in the case of Melhuish v. Collier, ${ }^{33}$ in which it was held that a party might examine his own witness upon prior contradictions, not with the view of discrediting him, but of refreshing his recollection and of getting the witness to correct himself. The court distinguished this procedure from calling other witnesses to testify that the witness made the statements which he denies. In I854 legislation in England brought the law back to the earlier position of Lord Denman, with the unfortunate exception that impeachment by proof of prior contradiction is permitted only when the judge is of the opinion that the witness is adverse. ${ }^{34}$

The development of the English law is duplicated in American law with the courts vacillating upon the rule, quite generally establishing it, and

${ }^{24}$ See note 20 supra.

${ }^{25}$ See note 22 supra.

${ }^{26} \mathrm{His}$ opinion had great influence, however, in obtaining legislative reform in England. It was set out at length in the Second Report of the Common Law Commissioners of England in I853 which resulted in partial removal of the inhibition. See pp. $x 5^{-19}$ of this report.

${ }_{27} 2$ Moo. \& Rob. ${ }_{53}$ (1838).

${ }^{28}$ Regina v. Ball, 8 C. \& P. 745 (1839), on which Erskine, J., said, “. . . you cannot call a witness, or give evidence not otherwise admissible, for the purpose of discrediting your own witness." Also Winter v. Butt, 2 Moo. \& Rob. 357 (I84I).

${ }^{29}$ Regina v. Farr, 8 C. \& P. 768 ( 1839 ).

${ }^{30}$ Allay v. Hutchings, 2 Moo. \& Rob. $35^{8}$ (184I).

${ }^{31}$ The Lochlibo, I4 Jur. 792, I Eng. L. \& Eq. 645 (1850). In this case the use of prior inconsistent statements was held objectionable because it permitted indirectly what a party could not do in a straightforward way, namely, to discredit his witness by general evidence.

${ }^{32}$ I7 and I 8 Vict. c. I25, § 22 (I854). See note 83 infra.

${ }_{33}{ }_{5}$ Q.B. 878, xr7 Eng. Rep. 690 (I850).

${ }^{34}$ For extensive discussion of all legislation dealing with the impeachment rule, see pp. 88-96 infra. 
then proceeding to qualify it, with varying degrees of success. The problem first appeared in this country in the North Carolina case of State $v$. Norris, ${ }^{35}$ in which the court permitted impeachment by showing the witness' contradictions, but without citing any authorities. The court stated:

Were not the solicitor allowed to impeach such evidence, a wide door would be open for acquittal of the prisoner by false testimony; the prisoner would have nothing more to do than cause his witnesses to be introduced on the part of the state. They might therefore pass for truth any falsities they might think proper to utter.

Shortly afterward, the rule of that state was changed, reaching the same result as the English cases..$^{36}$ In New York the exclusion was early established and still continues. ${ }^{37}$ In the federal case of Ellicott v. Pearl,,$^{38}$ in which an explanatory report of a survey was rejected for use of impeaching a party's witness, Judge Story said:

But, in truth, the evidence was offered to discredit in part his present testimony; and certainly, the demandants were not at liberty to discredit their own witness, by showing his former declarations upon the same subject; though they might show by other witnesses that he was mistaken.

The tendency in this country generally has been to accept the rule but enlarge the possibilities of self-impeachment. ${ }^{39}$ The doctrine of surprise has developed, which permits a party to interrogate his own witness to obtain self-contradiction..$^{\circ}$ Some courts have gone further and admitted independent proof of inconsistent statements where a party has shown that he was surprised, misled or deceived by the adverse testimony. ${ }^{4 x}$ The Illinois Appellate Court adopted this more liberal view in the case of

35 I Haywood (N.C.) 429, I Am. Dec. 564 (r796).

${ }^{36}$ Sawrey v. Murrell, 2 Haywood (N.C.) 397 (I806); State v. Taylor, 88 N.C. 694 (1883).

${ }^{37}$ Lawrence v. Barker, 5 Wend. (N.Y.) 301 (I830); Bullard v. Pearsall, 53 N.Y. 230 (I873); People v. Purtell, 243 N.Y. 273,153 N.E. 72 (1926); see Holtzoff, The New York Rule as to Impeachment by a Party of His Own Witness, 24 Col. L. Rev. 715 (I924). For discussion of the recent legislative proposal in New York, see pp. $9 \mathrm{x}-96$ infra.

${ }^{8}$ ro Pet. (U.S.) $4 \mathrm{I} 2,440$ ( 1836 ).

39 Hurley v. State, 46 Ohio St. 320, 2I N.E. 645 (1889); Bullard v. Pearsall, 53 N.Y. 230 , 23I (1873); State v. Wolfe, Iog W.Va. 590, x 56 S.E. 56 (x930); Stanley v. Sun Ins. Office, I 26 Neb. 205,252 N.W. 807 (r934); Alabama Power Co. v. Trall, 212 Ala. 638, то 3 So. 867 (1925); Sullivan y. U.S., 28 F. (2d) 147 (C.C.A. gth r928); Note, Am. Cas. 1914 B, Ir20-35.

40 Ibid.

${ }^{4}$ Selover v. Bryant, 54 Minn. 434, 56 N.W. 58 (1893); Hurlburt v. Bellows, 50 N.H. I05 (1870); Murphy v. State, I20 Md. 229, 87 Atl. 8 II (r9r3); Peopie v. Payne, I3I Mich. 474, 91 N.W. 739 (1902); Sturgis v. State, 2 Okla. Crim. 362, 102 Pac. 57 (1909); Dunn v. Dunnaker, 87 Mo. 597 (1885); George v. Triplett, 5 N.D. 50, 63 N.W. 89I (1895); State v. D'Adame, 84 N.J.L. 386 , $86 \Lambda$ tl. $4 \mathbf{r}_{4}$ (19:3); Schmeltz v. Tracy, II9 Conn. 492, I77 Atl. 520 (1935). 
National Syrup Co. v. Carlson, ${ }^{42}$ but little use has been made of it in application. Other decisions place Illinois among the states adhering to the common law principle of exclusion. ${ }^{43}$ The movement in our law to liberalize the right of impeachment follows the course which the English law was taking in the case of Melhuish v. Collier ${ }^{44}$ with the idea of surprise usually engrafted upon it.45 Decisive action uprooting the rule from its obscure but secure past has not been generally undertaken by courts or legislation. The most liberal tendencies have been at best conservative, and have sustained the principle of the rule, founded upon its a priori conceptions, without searching and testing its merits as a practical device for obtaining just decisions of causes in the course of litigation.

\section{ANALYSIS AND CRITICISM}

The prohibition against impeaching one's own witnesses has been justified by the courts on two grounds: (a) a party by calling and examining a witness thereby vouches for and guarantees him to the triers of fact; (b) if a party were permitted to impeach the witnesses whom he placed upon the witness stand, he would be in a position to control their testimony. The impeachment of a party's own witness by proof of prior inconsistent statements has been said to be objectionable for the additional reason that the jury might accept the impeachment testimony as proof rather than use it only to test credibility. Are these reasons sound in theory or in practice? Are they consistent with other rules of procedure? How do they operate in actual litigation?

\section{A. VOUCHING FOR A PARTY'S WITNESSES}

The cases upon the subject of a party's right to impeach his own witness are replete with statements as a reason for the rule that a party who offers a witness thereby represents him as worthy of belief. ${ }^{46}$ A typical expression of this reason for the rule is contained in the statement of Judge Rowell in the case of Cox v. Eayres in which he says:

It seems to be pretty generally conceded that a party cannot impeach his own witness by general evidence of his bad character for truth; and the reasons given for the

${ }_{42}^{2} 42$ Ill. App. 178 (I89r). See also Consolidated Coal Co. v. Seniger, I79 IIl. 370, 53 N.E. 733 (1899).

43 Chicago City R. Co. v. Gregory, 22I Ill. 59x, 77 N.E. III2 (I906); People v. Johnson, 314 Ill. 486, I45 N.E. 703 (I924); People v. Michaels, 335 Ill. 590 , I67 N.E. 857 (I929).

44 I5 Q.B. 878, Ix7 Eng. Rep. 690 (1850), supra note 33.

45 See notes 40, 4 I supra.

${ }_{46}^{6}$ Becker v. Koch, I04 N.Y. 394, Io N.E. 701 (1887); Wilson v. Prettyman, I95 Iowa 598, I92 N.W. 4I3 (I923); People v. Johnson, 3 I4 Ill. 486, I45 N.E. 703 (I925); State v. Wolfe, rog W.Va. 590, I56 S.E. 56 (1930); Underhill, Criminal Evidence \$ 42I (4th ed. 1935); 3 
rule are, that by offering a witness in proof of his case, a party thereby represents him as worthy of belief, and that thereafter to attack his general character for truth, would be not only bad faith towards the court, but in the language of Buller, 47 "would enable the party to destroy the witness if he spoke against him, and to make him a good witness if he speaks for him, with the means in his hands of destroying his credit if he speaks against him."48

Other common expressions used in the statement of this reason are that the party vouches for his witness or that he has guaranteed him.49 This reason has been indiscriminately applied both to cases in which the impeachment attempted was by proof of general evidence of character to attack veracity, and to those in which the method of proposed impeachment was the proof of prior inconsistent statements..$^{50}$ In either situation, however, the doctrine that a party guarantees his witness cannot be sustained upon rational grounds. There are two principal ideas back of the theory. The first is that a party is regarded as selecting his witnesses, which may have its root in the history of compurgation. The second idea is that a party sponsors what his witness says and this lies in the general theory of our modern adversary system of trial. The chief fault in the vouching theory lies in the lack of free choice in the selection of witnesses. There is a vital distinction between oath-takers and witnesses both in selection and function. Except in the case of character witnesses and expert testimony, parties under the adversary system do not choose any persons they might like to place upon the witness stand, but are forced to take those, good or bad, who by fate or chance happen to have been exposed to the opportunity of observing or hearing facts which pertain to the case on trial. ${ }^{51}$ Even a person choosing a course of life with the most exacting precautions is likely to find it necessary to call witnesses who are the least desirable when he has his day in court. The error of the vouching theory

Wharton, Criminal Evidence $\S 1389$ (IIth ed. I935); I Greenleaf, Evidence $\S 442$ (I866); 2 Wigmore, op. cit. supra note 1 , at $\S 898$.

47 Trials at Nisi Prius 297 ( 1767 ). $\quad{ }_{48}^{8} 55$ Vt. 24, 27 ( 1883 ). $\quad{ }_{49}^{4}$ See note 46 supra.

${ }^{50}$ For critical discussion on this point see Taylor, Evidence $\$$ ro47-49 (I848) Contra, Selover v. Bryant, 54 Minn. 434, 56 N.W. $5^{8}$ (1893). The courts which have broken away from the impeachment rule have done so only as to impeachment by prior inconsistent statements, interest, corruption, and bias. Mr. Wigmore in commenting on the deductions from the vouching theory says, "If the party is to be taken as guaranteeing the witness' credibility, clearly he is prohibited from exposing, by any means whatever, an error of that witness, and especially an error which carries with it an implication of other errors, from whatever source." 2 Wigmore, op. cit. supra note $\mathrm{r}$, at $\S 902$. This statement emphasizes the need for complete abolition of the rule.

sx Selover v. Bryant, 54 Minn. 434, 56 N.W. $5^{8}$ (1893); see May, Some Rules of Evidence, II Am. L. Rev. 264 (1876). 
is most apparent where the adverse party is called as a witness. The rule is ineffective to exclude the prior inconsistent statements of the adverse party because they are admissible as admissions. ${ }^{22}$ The courts, however, still hold that the party who produces his adversary as a witness vouches for his veracity and shall not be allowed to show him unworthy of credit generally. ${ }^{53}$ The unreasonableness of the doctrine is disclosed in the case of Webber v. Jackson, in which the plaintiff put the defendant upon the stand for the purpose of proving fraud under a judgment creditor's bill. Against the impeachment rule the court pointedly said, "But it seems a little incongruous to claim that a party who puts the defendant upon the stand for the express purpose of showing his fraud, thereby gives him credit for honesty." 54

The courts have uniformly rejected the idea that a party vouches for witnesses whom he is under a duty to call..$^{55}$ In a very real sense, with the exception of experts and those who testify as to character, most witnesses are necessary from the standpoint of the party. Indeed, in the case of technically necessary witnesses, the proponent often exercises choice in advance. Comparatively, the ordinary witness more nearly fits a rational classification of necessary witnesses. There is a distinction, in that the law places no duty upon him to call the particular witness as in the case of a necessary witness, but if he expects to present his case at all in court, he must select those available or have none.

From another aspect the vouching theory fails to take into account the inability of a party to select witnesses whose testimony he may predict with certainty. Jeremy Bentham, in his attack upon the vouching theory stated that it rests upon the false axiom that:

All men belong to one or the other of two classes-the trustworthy and the untrustworthy. The trustworthy never say anything but what is true: by them you can never be deceived. The untrustworthy never say anything but what is false: so sure as you believe them, so sure are you deceived. ${ }^{6}$

52 People v. Michaels, 335 Ill. 590 , r67 N.E. 857 (r929); Lambert v. Armentrout, 65 W.Va 375, 64 S.E. 260 (r909); Koester v. Rochester Candy Works, x94 N.Y. 92, 87 N.E. 77 (rgog).

s3 Mississippi Glass Co. v. Franzen, 443 Fed. 5or (C.C.A. 3 d x906); Bushnell v. Bushnell, I03 Conn. 583, I3I Atl. 432 (I925); Royer v. Erb, 219 Iowa 705, 259 N.W. 584 (r935).

${ }^{54} 79$ Mich. 175, 179, 44 N.W. 591, 592 (1890). See, under statute, Fleegar v. Consumer's Power Co., 262 Mich. 537, 247 N.W. 74r (I934).

ss Thompson v. Owen, I74 Il. 229, $5 \mathrm{r}$ N.E. I046 (1898); In re Estate of Warren, I38 Ore. 283,4 P. (2d) 635 (193I); State v. Slack, 69 Vt. 486, 38 Atl. 3 Ix (I897) (holding that the State in a criminal case may impeach its own witnesses on account of its obligation to bring forward all witnesses irrespective of their character).

${ }_{56}{ }_{2}$ Bentham, Rationale of Judicial Evidence 64 ( $(827)$, quoted in 2 Wigmore, op. cit. supra note $r$, at 256 . 
Common experience demonstrates that the truth may be misunderstood by those presumably reliable, and that persons of questionable character may, and perhaps most often do speak the truth. The use of either class of witnesses should not carry the penalty of being denied the right to impeach them if false in their testimony.

This leads us to the second inquiry as to the extent to which a party, by presenting a witness in court, sponsors what the witness says. The theory that a party should be held to do so lies in our adversary system of trial. Under the early inquisitorial system, the jurors, acting upon their own knowledge or investigation, or hearing such witnesses as happened to be present, did not look at the witnesses as being connected with the parties. Under the adversary system, by which the parties on each side present only the witnesses by whom they expect to sustain their case, it is somewhat natural to regard the witnesses as belonging to the party who calls them. The litigant is permitted to emphasize his strength, minimize his own weaknesses and magnify the weaknesses of his opponent. Consistent with this scheme is the thought that a party vouches for the persons he presents as witnesses although he may freely attack those of his opponent.

The common law method of pleading gives some light upon the extent to which the adversary system requires each party to investigate his case in advance and make a final determination of the facts before trial. The litigant was required to know with approximate certainty, in advance of trial, what his proof would establish, and to state with nicety and exactness the issue upon which he expected to rest his case. The penalty for variance was severe. The same particularity was demanded in the older criminal law indictments. This detailed investigation by the parties prior to trial exacted under the early law accords with the notion that the parties should be held to guarantee their witnesses.

Later, the rules of pleading became more flexible and more adaptable to the necessity of the parties who were unable to know in advance of trial just how their evidence would develop.57 Plaintiffs were allowed to state their cause of action in several counts, and defendants were permitted to make inconsistent pleas. Permission was granted to allow amendments during trial to make the pleadings conform to the proof. The modern method of code pleading was designed to eliminate the ex-

57 Clark, Code Pleading 3I4 (I928); Shipman, Common Law Pleading 203-6 (Ballantine ed. I923); Stephen, Pleading 73-75, I66, 8 I (Williston ed. I895); Pomeroy's Code Remedies $\$ \S 447-449,456,457$ (5th ed. I929); Scott, Fundamentals of Procedure, c. 5 (r922); Thompson, Trials $\$ \S 2310,23$ I2 (2d ed. I9I2). 
treme exactness required in the early law. Likewise the present day indictment is a totally different instrument than in the past. From this great change in pleading, it is apparent that under the adversary system the law has definitely recognized the inability of a party to know in advance what his proof will be, and the gross unfairness which would result if he were compelled to rely only upon the facts as known by him before trial.

These devices by which parties are permitted greater freedom in pleading reveal that the adversary theory has given way in those places where its application would work a demonstrable injustice. Likewise, in connection with the impeachment rule, the adversary theory of trial has yielded to the right of a party to impeach his own witness in the case of necessary witnesses..$^{8}$ Also, it defeats its object if it compels a party to keep essential proof from the triers of fact. Therefore, it has not prevented contradiction by other witnesses..$^{59}$ It has partially opened the way for impeachment by permitting examination of the witness himself for the purpose of refreshing his recollection and inducing him to tell the truth..$^{60}$ It has also permitted impeachment of a witness whom a party called, but from whom he obtained no material testimony. ${ }^{6 x}$ It is illogical to hold that a party vouches for his witnesses when under the adversary system he could not effectually guarantee them if he desired to do $\mathrm{so}^{62} \mathrm{It}$ is reasonable to require all possible preparation in advance of trial but it is an unjustifiable extension of the theory to deny a party the right to attack a witness from whom investigation indicated favorable testimony would be given. As the adversary theory has gradually conformed to the demands of reality and has recognized the inability of a party to predict with accuracy what his testimony will be in advance, it is time that it should carry this principle to the repudiation of the vouching theory which has resulted in a denial of the right of a party to impeach his own witnesses.

\section{B. CONTROL OF WITNESSES}

Mr. Justice Buller's statement quoted by Judge Rowell suggests that the power to impeach involves the power to destroy. ${ }^{63} \mathrm{Mr}$. Wigmore elaborates it thus:

$5^{8}$ See note 55 supra.

59 Alexander v. Gibson, 2 Camp. 555 (I8Ir); Lewis v. Wabash R. Co., 142 Mo. App. 585, I2I S.W. Iogo (I909); Olmstead v. Winsted Bank, 32 Conn. 278 (1864); Chicago City Ry. Co. v. Gregory, 22 Ill. 59I, 77 N.E. III2 (I906).

60 See note 39 supra.

6x Fall Brook Coal Co. v. Hewson, 158 N.Y. $\times 50,52$ N.E. 1059 (189g).

62 Selover v. Bryant, 54 Minn. 434, 56 N.W. 58 (1893). $\quad{ }_{63}^{6}$ See text to note 48 supra. 
The true foundation of policy (so far as there is any) is here manifest. If it were permissible, and therefore common, to impeach the character of one's witness whose testimony had been disappointing, no witness would care to risk the abuse of his character which might be launched at him by the disappointed party. This fear of the possible consequences would operate subjectively to prevent a repentant witness from recanting a previously falsified story, and would more or less affect every witness who knew that the party calling him expected him to tell a particular story. . . . Speculative as this danger may be, it furnishes the only shred of reason on which the rule may be supported. ${ }^{64}$

There is no indication that Bentham received such an impression from Buller's statement, and in the earlier cases no emphasis is put upon the potential threat of coercion. Does it have any basis in fact?

How fearful persons on the witness stand may be of impeachment is a matter of much conjecture. The witness on the stand is, of course, in a position of public obervation, holding the center of attraction of jury, court and courtroom. What he says or does, and what happens to him in the battle between attorneys, are matters of comment and are liable to be heralded in the newspapers. If inconsistencies of a witness' statements were permitted to be shown, although involving no moral degradation, they might sometimes be embarrassing and become an injury to his self-esteem. If proof is permitted of contradictory statements which he denies having made to others, the witness may be made to appear either muddle-headed or a falsifier. If his moral character is attacked his life becomes an open book, exposed for public comment. Psychologists speak of the personal ego as one of the dominating characteristics in human behavior. Pride of opinion, self-esteem, and the desire to be thought well of are as a matter of common experience recognized as factors significant in shaping the conduct of people, and these human characteristics are accentuated in the courtroom. How does this relate to the theory that the power to impeach a witness whom a party calls gives the power to control his testimony?

\section{Impeachment by Bad Character}

We will first consider the operation of the rule prohibiting impeachment by evidence of bad character. The fear theory of the impeachment rule assumes that a witness would testify falsely, for the party who calls him, to avoid being subjected to the foregoing consequences of impeachment. Restricting impeachment by the party who called him to testify is supposed to assure freedom of the bad witness to become honest and to make it easy for him to testify to the truth. The need of the rule to accomplish this result must be judged from the relation of the witness to the counsel

612 Wigmore, op. cit. supra note $\mathrm{r}$, at $\$ 899$. 
in charge of the case because it is through the counsel that the coercion would be exercised. If we assume the counsel is honest it is difficult to see any occasion for the rule upon this ground. If the witness knew his character were bad and knew the law, he could inform the counsel in advance of trial of the facts as he knew them, and it is inconceivable that an honest counsel would attempt to coerce the witness into stating the facts favorable to his cause by threats of impeachment. Thus there is an available and simple means of attaining the same result without the use of the impeachment rule. If we assume that the witness is ignorant either of his own bad character or of the law, again there would be no occasion for the rule to operate. The witness would not be conscious of the danger which he might encounter and therefore the rule designed to assure him freedom in giving testimony could have no effect upon him.

The operation of the fear theory seems to require a dishonest counsel who presents a witness whom he knows does not want to testify as expected and the counsel uses the whip of impeachment to hold the witness to the expected testimony. For the witness to be put in fear, he would need to know that his character was regarded as bad, and believe that the counsel intended to use it to impeach him if he failed to testify as expected. The witness would need to feel that nothing could be gained by informing the counsel of the true facts in advance of trial because he would call him to testify anyway and would employ the threat of impeachment to coerce his testimony. Such a situation seems improbable both from the standpoint of the attorney and of the witness who would yield to such actual or implied threats. Furthermore, if the dishonest counsel knew in advance that the witness did not believe the facts which were expected from him, and did not desire to testify, he would not be safe in using the witness, as he could not know whether the danger of impeachment would in fact cause the witness to falsify in his favor. The rule is not generally considered upon specific tests of its operation but is judged upon the principle of coercion as an abstract conception. Here the rule likewise fails because it overlooks another factor, namely that the counsel for the adverse party might impeach the witness by the means held not available to the party who called him. The witness would be escaping impeachment only from one of the parties. If he assumed that by giving false testimony he would avoid impeachment by the party who called him, he most surely ought to expect impeachment by the opposite party who would be justified in doing so. This point would seem to rebut conclusively the control theory as applied to general character evidence. Furthermore, the control theory ignores the danger that the witness might be charged with perjury, which 
would have a forceful counteracting influence against the fear of being impeached.

\section{Impeachment by Interest and Bias}

The control theory of the impeachment rule has little or no opportunity to operate in the case of impeachment by interest, hostility, or bias, as these qualities involve no degradation of the witness. ${ }^{65}$ The very elements of the hostility or interest repudiate the opportunity for the theory to operate, as they show the disposition of the witness not to yield to the wishes of the party who called him. There is one situation, however, in which this may not be true. In case the attempted impeachment by bias disclosed disgraceful conduct, the witness might seek to avoid the embarrassment by giving favorable but false testimony. However, it is important to realize that if the counsel for the other side of the case had called the witness, the same impeachment would be available. The coercion by the adversary would then be quite as efficient as if the adversary had called the witness as his own. Yet the law permits this impeachment of the witnesses called by an opponent. The only effective means of preventing the coercive influence of impeachment by proof of disgraceful conduct would be to eliminate that type of impeachment altogether.

\section{Impeachment by Corruption}

In the case of impeachment by corruption, similar principles would apply as in the case of impeachment by evidence of bad character, with the exception that the range of use of such proof is more limited. If the corruption had been in the interest of the party calling the witness, he would hardly be in a position to impeach the witness by it.

If the witness had been corrupt in suborning testimony for the party's adversary, it could not be reasonably expected that the witness would give favorable testimony on the other side. The very fact of corruption in favor of an adversary notifies the counsel that he can not look for favorable testimony from the witness. This method of impeachment is more generally usable against an adversary's witness, rather than by the party

65 Cases on application of the rule upon interest and bias are not numerous and are in conflict. See Fairly v. Fairly, 38 Miss. 280 ( 8859 ); In re Mellen's Estate, 56 Hun (N.Y.) 553, 9 N.Y.S. 929 (I890); O'Rear v. Manchester Lumber Co., 6 Ala. App. 46r, 60 So. $45^{2}$ (I9I2). In Southern Bell Tel. \& Tel. Co. v. Mayo, I34 Ala. 64I, 33 So. I6 (Igo2), it was held that by the general rule that one may not impeach his own witness, he may not show that the witness is insane. But in State v. Alexander, 89 Kan. 422, I3I Pac. I39 (I9I3), the prosecution was permitted to prove that one of its witnesses was drunk at the time of observing the facts about which he testified. Likewise in State v. Lee, 85 S.C. Ior, 67 S.E. I4I (I9I0), it was held that the rule did not apply to evidence showing that the witness for the state was the putative father of the accused. 
who calls him. However, assuming the control theory might operate in favor of a party who called the witness, it would also operate to control the witness if he had been called by the adversary, yet impeachment in this instance is permissible. The situation in which impeachment by corruption does aid a party in testing the credibility of his own witness is shown in the case of State $v$. Moon ${ }^{66}$ in which the witness before trial had informed the prosecution of the statements made by the defendant of his plans concerning a larceny. When called and examined, he denied knowledge of these statements. The prosecutor was allowed to cross-examine the witness about them after which the witness was arrested for perjury. The next day the witness called for the prosecuting attorney, changed his statement, and when placed upon the witness stand retold the original story and gave the details in respect to subornation by the defendant which had caused him to testify falsely. Mr. Wigmore in his comment upon the opinion upholding the procedure says, "It is a brilliant example in repudiating the artificial trammels of the present rule." ${ }^{67}$ It should be observed that in this case there could be no opportunity for the control theory to operate because the witness could not have expected the prosecutor to have known of the corruption. Witnesses would conceal such facts from the party who called them, which would prevent them from fearing that the party would use the proof of corruption against them. Thus the coercion theory would fail to operate.

\section{Iv. Impeachment by Inconsistent Statements}

We will next consider the operation of the fear theory in connection with impeachment by prior inconsistent statements. For the principle to operate, it is necessary to assume that the first story is incorrect and that a penitent witness desires to recant and give true testimony when called in court. The fear theory assumes that the witness would not do so if he knew it were possible to prove that he had made a former contradictory statement. Again we must consider the matter from the standpoint of the honest and the dishonest counsel. If the witness realized that he had made the former statement by mistake and he informed the counsel of this fact before trial, an attorney acting in good faith would not call upon him to testify. The witness, therefore, could avoid the experience of being impeached in a much easier manner than by giving perjured testimony. If the witness, however, did not inform counsel of the mistake before trial but changed his story upon the witness stand, the consequences of impeachment by this method could not be serious. There is nothing dis- 
graceful about being mistaken and the witness would have the opportunity of correcting and explaining his former statement.

If we assume a dishonest counsel or an attorney who did not believe that the witness was telling the truth, it is possible that he would endeavor to use this method of impeachment to bring the statements into the case although the witness previously informed him of their error. This, however, could not operate to coerce the witness. A dishonest counsel might claim that the former statement was true and that the witness falsified when he changed his story although the counsel believed otherwise. The fact that the witness himself admitted the former statement would tend to nullify the effect of this accusation. A candid explanation on the part of the witness would make it difficult for an unscrupulous attorney to disparage the witness unduly and could easily prejudice the attorney in the eyes of the jury. There is hardly a slight possibility of coercion by the use of prior inconsistent statements; surely not enough to make application of the control theory plausible.

\section{v. The False Premise of the Control Theory}

The chief fault of the control theory as applied to all types of impeachment lies in the fact that it assumes that all witnesses who give destructive testimony to the party who calls them, are testifying to the truth. Unfortunately the rule has been most often regarded as prohibiting the impeachment of a penitent witness, who previously told a false story and desires to recant and state only what is true, or of a witness who is being compelled to testify falsely under the pressure of having his bad reputation exposed if he does not do so. The first story told, surely in many cases and likely in most cases, represents the truth, or at least an uncertainty which should call into question the correctness of testimonial divergence in court. When it is considered how many influences might be brought to bear to make a witness change his story, objections to the rule may be appreciated.$^{68}$ Sympathy for the accused in criminal cases plays a large part in causing witnesses to change their testimony, as many people dislike to take an active part in causing imprisonment, particularly when friends or relatives are involved. The paying-off process in the form of reparation of the loss is often potent in persuading prosecuting witnesses to repudiate their former statements and to develop an attitude favorable to the defense. Bribery also is a significant factor in causing witnesses to change stories at the trial, in both civil and criminal cases. Threats of physical violence, control by gang domination, and the fear among some witnesses of being ${ }^{68}$ See also, Hurlburt v. Bellows, 50 N.H. I05 (r87o); Selover v. Bryant, 54 Minn. 434,56 N.W. 58 (1893). 
disrespected and ostracised for turning state's evidence weigh heavily in preventing the truth from being told. The Association of Grand Jurors of New York County in its program to abolish the impeachment rule, emphasized this aspect of the problem, stating:

Under the existing law in New York, the District Attorney cannot fight back when the defendant tampers with his witnesses. One story may be told him in his office, and an entirely contradictory one on the witness stand. The law will not allow him to expose the lie. Likewise the attorney for the defense who calls a witness is presumed, in broad language, to vouch for his character and story and cannot impeach him. As a result, in many criminal actions where terrorists are on trial, a witness who originally gave the prosecutor information useful to the people repudiates his story through fear. ${ }^{69}$

There is no sound basis for assuming that destructive testimony given by a party's own witness is the truth told by a recanting witness, nor is there a realistic foundation for the hypothesis that fear of impeachment dominates witnesses throughout their examination. The latter conception is at best a fanciful psychological speculation, and could not appreciably affect an honest and reputable witness, nor is it likely to react upon the disreputable. ${ }^{70}$ As shown in the foregoing analysis, the sphere in which the coercion doctrine may operate is very limited, and in most situations could be avoided if the witness desired.

\section{IRPEACHING EVIDENCE AS SUBSTANTIVE}

A reason frequently urged in support of the impeachment rule is the danger that the jury may accept the impeaching statements as substantive proof. ${ }^{7 x}$ This could, of course, apply only in the attempt to impeach by proof of prior inconsistent statements. Also, no legitimate purpose of impeachment can be served by introducing prior statements against a witness who has given no damaging evidence. The courts have discussed this problem at length, uniformly holding the testimony inadmissible as

${ }^{69}$ Wright, I935 Legislative Program of Association of Grand Jurors of New York County, I2 The Panel 25, 26 (1934).

$7^{70} 2$ Wigmore, op. cit. supra note $\mathrm{r}$, at $\S 899 ;$ May, op. cit. supra note $5 \mathrm{I}$.

7 Alabama Power Co. v. Hall, 2 I 2 Ala. 638, I03 So. 867 (r925); Ewer v. Ambrose, 3 B. \& C. 746 (1825); Langford v. Jones, 18 Ore. 307, 22 Pac. I064 (1890); Katz v. State, 92 Tex. Cr. R. 629, 245 S.W. 242 (r922); State v. Gardner, I35 La. 746, 66 So. I8I (I9I4); Best, Evidence $\S 440$ (I849); Taylor, Evidence § 1048 (I848); 2 Wigmore, op. cit. supra note $\mathrm{r}$, at $\$ \S 903,904$ (8), ror8; Jones Evidence $\$ 853$ (3d ed. I924). The objection to the use of impeachment evidence as independent proof is well recognized. Donaldson v. New York, N.H. \& H.R. Co., I88 Mass. 484, 74 N.E. 9I5 (r905). Most of the cases, however, which assert this objection as ground for prohibiting impeachment of a party's own witness deal with the single problem of excluding ex parte statements by a witness who has given no damaging proof in court, and which would thus have no impeachment value. See note 72 infra. 
hearsay. ${ }^{72}$ The problem is presented only when a witness gives destructive testimony to the party who calls him, and has previously made favorable declarations to the contrary. Is the danger of use by the jury as substantive evidence a valid objection to the right of impeachment?

Upon three grounds this reason for the rule can not be sustained. First, the application of this theory is inconsistent with the accepted doctrine that a counsel may obtain an admission from his own witness that he has made contradictory statements. In case a party shows that he is surprised by the unfavorable testimony, he may make inquiry of his witness concerning prior statements, to refresh his memory, to probe his conscience, and to permit him to explain his divergencies if he admits them..$^{73}$ If the witness admits making the former statement but maintains that it is not correct, the statement is nevertheless before the jury just as the impeachment statement would be. The danger of receiving the contradiction as proof would be the same as if other witnesses proved the former statement. 74

Second, the inconsistent application of this reason pointedly appears in connection with impeachment of witnesses of an adversary. The identical chance of misuse of impeaching statements exists where the witness has damaged the proponent as where the witness had damaged the opponent. Yet in the latter case prior inconsistent statements are universally admitted without fear that the triers may accept the impeaching statements as substantive evidence.

Third, the suggestion of Mr. Wigmore, ${ }^{75}$ that the hearsay rule be held inapplicable to ex parte statements of a witness who is in court, may be profitably employed to refute this reason for the impeachment rule. The fact that the witness is present in court, sworn upon oath, and subjected to cross-examination of the adverse party, substantially eliminates the opportunity for error or misjudgment in receiving the former statement. Although the prior statements are technically hearsay every condition is met, which otherwise calls for the exclusion of such testimony. If there is no real danger, even assuming the jury were to accept the prior inconsistent statements as proof, that reason for the rule can not be urged where there is a legitimate basis of admitting the statements for impeach-

72 Crago v. State, 28 Wyo. 215, 202 Pac. Iogg (I922); Kuhn v. United States, 24 F. (2d) 910 (C.C.A. 9th I928); Sullivan v. U.S., 28 F. (2d) I47 (C.C.A. gth I928); People v. Spencer, 58 Cal. App. I97, 208 Pac. 380 (I922).

${ }^{73}$ State v. Wolfe, 109 W.Va. 590, 156 S.E. 56 (I930), and note thereto, 74 A.L.R. I039 (1930).

74 State v. D'Adame, 84 N.J.L. 386,86 Atl. 4I4 (Igr3).

752 Wigmore, op. cit. supra note $\mathrm{I}$, at $\S$ ror8. 
ment purposes. Fortunately the impeachment rule has been avoided where the adverse party is called as a witness, because the prior statements are received as admissions. Clearly as to non-party witnesses, evidence of former statements ought to be admitted with instructions by the court, limiting its use to impeachment, the same as in innumerable places in the law of evidence, proof is admitted with limitations upon the right of the jury to consider it.

\section{LEGISLATION IIBERAIIZING THE IMPEACHMENT RULE}

The statutes modifying the common law rule prohibiting a party from impeaching his own witness have an interesting history, commencing with the English act of 1854 , and concluding with the recent legislative reform proposed in New York eighty-one years later. The English act is usually thought of as the first enactment upon the subject and as having been the general pattern for subsequent statutes appearing in Anglo-American countries. Other acts are usually described in respect to their similarity to or difference from the English act. As a matter of fact, the Scotch law was amended three years before the English act to permit impeachment of any witness, including thereby a party's own witness, by proof of prior contradictions, and it was not bound up with the limitation that the witness prove adverse. ${ }^{76}$ And peculiarly enough the English act did not originate in England, but was borrowed in great part ${ }^{77}$ from the Report of the Commissioners on the New York Code of Civil Procedure, ${ }^{78}$ which was submitted to the New York legislature and bears the date of December 3I, I849. The sections of the report upon which the English act is based never became a part of the law of New York. The impeachment rule continues in full force in that state, in spite of the diligent efforts for law reform urged before the legislature last year. A bill changing the rule was presented by the Commission on Administration of Justice, and was

${ }^{76} 1852$ Act. $15 \& 16$ Vict., c. 27, III.

77 Taylor, Evidence $\S \mathrm{I} 282 \mathrm{n}$. I (2d ed. I855); Id. at $\$ \mathrm{I} 426 \mathrm{n}$. (a) (r2th ed. I93I). This note states that the enactment was taken from the New York Civil Code but these provisions were in the Commissioners' Report only and were not enacted.

${ }^{78}$ Commissioners' Report, New York Code of Civil Procedure $\$ 1845$ (r849). The party producing a witness, is not allowed to impeach his credit by evidence of bad character but he may contradict him by other evidence, and may also show that he has made at other times, statements inconsistent with his present testimony, as provided in section 1848 . Sec. 1848 . A witness may also be impeached by evidence that he has made, at other times, statements inconsistent with his present testimony; but before this can be done, the statements must be related to him, with the circumstances of times, places and persons present; and he must be asked whether he has made such statements, and if so, allowed to explain them. If the statements be in writing, they must be shown to the witness, before any question is put to him concerning them. 
sponsored by the Association of Grand Jurors of New York County as a part of their 1935 Legislative program. ${ }^{79}$ The bill was passed upon the floor of the Senate but was never reported out of the Judiciary Committee of the Assembly. ${ }^{80}$ It has met the same fate so far as did the attempt in I849 to remedy the evils of the common law rule. The new measure, however, is materially different from the earlier one, is much broader in its provisions, and presents the first comprehensive treatment of the problem. ${ }^{8 x}$ The bill will undoubtedly be urged again, and the success of its enactment is quite probable. ${ }^{8 z}$ The former report of the Field Commission has had great influence in this country through the indirect method of the English act and quite possibly by direct reference because the legislation in the United States corresponds more nearly with the Field proposal than with the English law. This, however, could have been done as well by practical and natural modification of the English act as by taking the New York proposal which, by not being adopted, lost much of its prominence.

Unfortunately the English act was very limited in its scope and at most but partially opened the way to impeachment by prior inconsistent statements of a party's own witness. The act at first applied only to civil proceedings but in 1865 was extended to all courts of judicature, civil and criminal. The form of the English act is confusing, but in substance it provides $^{83}$ that a party producing a witness in court:

(r) shall not be allowed to impeach his credit by general evidence of bad character,

(2) may contradict him by other evidence,

(3) may prove that he has made at other times a statement inconsistent with his present testimony, provided,

(a) the witness prove adverse in the opinion of the judge,

(b) leave of the judge be obtained by counsel,

(c) a foundation for impeachment is laid.

In the Canadian Provinces this statute was uniformly adopted verbatim

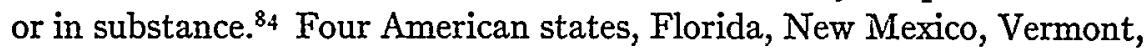

79 Recommended Changes in Practice, Procedure and Evidence, Commission on the Administration of Justice in New York State, p. 6I, $\$ 38$; Wright, I935 Legislative Program of Association of Grand Jurors of New York County, 12 The Panel 25, 26 (I935).

${ }^{80}$ Greene, ${ }_{935}$ Legislative Program Results, I3 The Panel 3, 7 (1935).

${ }^{8 x}$ See text to note roo infra.

${ }^{82}$ See note 8o sipra.

${ }^{8}{ }_{3} 17$ \& 18 Vict. c. $125, \$ 22$ ( 1854$)$ : "A party producing a witness shall not be allowed to impeach his credit by general evidence of bad character; but he may, in case the witness shall in the opinion of the judge prove adverse, contradict him by other evidence, or by leave of the judge prove that he has made at other times a statement inconsistent with his present testimony."

${ }_{4}$ Wigmore, Evidence $\S 905$ nn. 2, 3 (2d ed. 1923, supp. 1934). 
Virginia (and Hawaii) have statutes in substance identical to the English Act. $^{85}$ In the Louisiana Code of Criminal Procedure the elements of both hostility and surprise are included, and it is further provided that surprise does "not arise out of the mere failure of the witness to testify as expected, but out of his testifying upon some material matter against the party introducing him and in favor of the opposite side." Columbia there is a statute permitting a party to impeach his own witness by proof of prior inconsistent statements in event of surprise with the included proviso that if the statements are made to a party or his attorney before the trial, the requisite element is met. ${ }^{87}$ This position is similar to that of the federal and some state courts without statute but gives more assurance for the reception of independent proof of the impeachment statements. Georgia ${ }^{88}$ and the Philippine Islands ${ }^{89}$ have likewise adopted the surprise theory in their statute but by different language, the former making the condition of a party's right to impeach his own witness that he be "entrapped" and the latter that he be "misled" by the witness.

The Massachusetts statute ${ }^{90}$ represents the legislation in ten states, ${ }^{9 x}$ Alaska, ${ }^{22}$ and Porto Rico. ${ }^{93}$ It reads as follows:

The party who produces a witness shall not impeach his credit by evidence of bad character, but may contradict him by other evidence, and may also prove that he has made at other times statements inconsistent with his present testimony [foundation for impeachment required].94

In the case of Ryerson v. Abington decided in the same year that the statute was enacted in Massachusetts, the court said in reference to the

${ }_{85}$ Fla. Comp. Gen. L. I927, §4377; N. Mex. Ann. Stats. I929, c. $45, \S 607$; Vt. Pub. L. I933, $\S$ I702; Va. Code 1930, $\$ 6215$ (with additional provision that court shall instruct the jury not to use the prior statements except for purpose of impeachment). Hawaii Rev. L. I925, § 2624 .

${ }^{86}$ Louisiana Code Crim. Proc. I932, $\$ \S 487,488$.

${ }^{87}$ D.C. Code 1929, tit. 9, § $2 x$.

${ }^{88} \mathrm{Ga}$. Code $1933, \S 5879$. The provision first appears in $186 \mathrm{I}$.

89 Philippine Islands, Code Civil Proc. Igor, § 340.

${ }^{\circ}$ Mass. Gen. L. I932, c. 233, §§ 22, 23.

9r Ark. Dig. I921, § 4I86; California Code Civ. Proc. I931, § 2049; Idaho Code 1932, c.I6, § I207; Burns' Ind. Stats. 1933, c. 2, § 1926; Carroll's Ky. Code 1932, § 596; Mont. Rev. Stat. I921, § ro666; Ore. Code I930, c. 9, § 1909; Texas Code Crim. Proc. I928, § 732; Wyo. Rev. Stat. I93 I, c. 89 , \& I706.

92 Alaska Comp. L. I933, § I499.

93 Porto Rico Rev. Stat. I9Ir, $\$ \S 1524,6275$. The requirement that the party be surprised and the witness prove adverse has been read into the statute, People v. Plata, 36 P.R. $53^{\circ}$ (I927).

94 See note 87 supra. 
statute,, 95 "It is taken almost verbatim from the English statute . . . . omitting however the qualification of the act-'in case the witness shall in the opinion of the judge prove adverse'-and the limit of the right to prove such inconsistent statements 'by leave of the judge' only." The Massachusetts statute may have come from the English act, but it has a striking similarity to the Field Commission Report of $1849,{ }^{36}$ which is believed to be the true source of all legislation upon the subject prior to the recent New York proposal.

The exact origin of our legislation upon this subject is interesting, in that it discloses the common tendency to copy statutes or first proposals, rather than make an independent investigation of the merits and suffciencies of proposed remedies. The earlier legislation stopped far short of an adequate treatment of the problem by dealing only with impeachment by prior inconsistent statements. The serious objection to it is the failure to admit other impeachment, which, if regarded by the law as worth while for testing the truth of an adversary's proof, would serve in the main the same purposes of exposing falsity and error in the case of a party's own witnesses.

THE PROPOSED NEW YORK LEGISLATION

The proposal of the Commission on the Administration of Justice in the State of New York recognizes and attempts to cure the defects and limitations of previous legislation pertaining to the impeachment rule. Whereas all former legislation has expressly prohibited the impeachment of the witness of a party by proof of his general character and has enlarged admissibility only to the extent of authorizing proof of prior inconsistent statements, the New York proposal has attempted to deal with all principal methods of impeachment. It is by far the most comprehensive and carefully drawn measure upon the subject, and anticipates most of the problems with much nicety. Its provisions are as follows:

The party who calls a witness shall not be precluded from impeaching him by proof of prior contradictory statements or by evidence of bias or corruption, or in any other manner, except that the party calling the witness shall not be permitted to prove the bad reputation of the witness for truth and veracity, or to prove that he was convicted of a crime unless such proof is offered prior to or at the beginning of the examination

${ }_{95}$ I02 Mass. 526, 530 (1869). Before the act the Massachusetts law followed the rigid common law rule. See Adams v. Wheeler, 97 Mass. 67 (I867). The Massachusetts courts have not read into the statute the surprise or adverse element, but permit impeachment when injurious testimony is given. Brooks v. Weeks, r2r Mass. 433 (I877).

${ }^{96}$ For text of report, see note 78 supra. 
of the witness or unless the court is satisfied that such bad reputation or conviction was discovered by the party subsequent to the witness' giving his testimony.97

The first part of the proposal, it will be observed, accomplishes all that is done under the Massachusetts and English statutes and more. It opens the way for a party to prove prior contradictory statements of his own witness, which is the total accomplishment of all previous legislation. It is not fettered with requirements that the witness be adverse or that the party be surprised. In this it is like the Massachusetts type of statute. It also contains the additional provision that the party producing a witness may impeach him by evidence of bias or corruption. The English act requires that the witness prove adverse in order to permit his prior contradictory statements to be introduced. The New York proposal contemplates the admission of proof of those things which make the witness adverse for the direct purpose of impeachment, rather than as a condition to the introduction of previous contradictions. It provides for broad construction in this respect because it contains a supplemental phrase permitting impeachment "in any other manner" subject to specified exceptions. The whole tone of the proposed act is different from former legislation, which explicitly permitted only proof of prior contradictory statements to escape from the inhibition invoked by the common law.

The New York proposal is the first attempt to admit impeachment of a party's own witness by proof of general reputation for credit, and the previous conviction of a crime. The common law has been firmly set against such proof upon the theory early expressed by Judge Buller that a party should not be able to make beneficial use of the testimony of a witness generally unreliable if the witness prove favorable, but be permitted to blacken his character if the testimony turned out to be against him..$^{98}$ This position is not without merit. The ostensible unfairness of being willing to withold what the party knew about the witness until his testimony was given and then, if it turned out to be bad, to attack his general character, makes a strong appeal for excluding this testimony. The result, however, of the common law in making a positive exclusion of this testimony often puts a party in a difficult position. If the witness proves favorable he will be attacked by his opponent, and if the witness is damaging, he is helpless to expose him. The party is always in danger of suffering

97 Recommended Changes in Practice, Procedure and Evidence, Commission on the Administration of Justice in New York State, p. 6I, § 38, Proposed Section 343-a of the Civil Practice Act. Also appears in Report of the Commission on Administration of Justice in New York State 299 (I934).

${ }_{98}$ Trials at Nisi Prius 297 ( $I 767$ ). 
the ill effects of having the adverse party put him in the position of having produced an unreliable witness, and yet he is not in a position to make a similar disclosure. The problem thus presented is how to deal fairly with the party and also have the party deal fairly with the court. This matter is disposed of in the New York proposal by making it possible for a party who produces a witness whose character is subject to attack to introduce such proof at the beginning of the examination or at a later time if he did not have knowledge of those facts when the witness was first examined. The bill does not prevent such proof, but it requires that if a party is going to use it, he must do so when his witness gives favorable testimony as well as when he gives objectionable testimony.

This part of the proposed statute generally meets all objections which might be urged in support of prohibiting proof of general character. The coercion theory is dispensed with because the party has done all he could do to injure the witness before he has testified upon the facts of the case. The guarantee theory is dispensed with because the party discloses at the outset that he is not guaranteeing the witness but is showing his objectionable character so that the jury may have that testimony in evaluating the proof upon the facts in issue. Theoretically the proposed statute is sound, and works practically, in the case of impeachment by previous conviction of crime. This phase of the problem had been presented in the New York case of People v. Minsky, in which the prosecutor called a witness whom he knew to be adverse and opened the examination by disclosing his bad criminal record. The New York court, upholding the procedure, said:

The district attorney put her on the stand as a hostile witness to get what he could from her. By so doing he did not necessarily present her as a witness of good moral character. The law does not limit a party to witnesses of good character, nor does it compel a party to conceal the bad record of his witnesses from the jury, to have it afterwards revealed by the opposing party with telling effect. Such a rule would be unfair alike to the party calling the witness and the jury. Men have been convicted of murder in the first degree by the evidence of admittedly dangerous and degenerate witnesses, law-breakers and professional criminals. .... But when a disreputable witness is called and frankly presented to the jury as such, the party calling represents him for the occasion and the purposes of the trial as worthy of belief.99

In respect to proof of previous conviction of a felony, there is no difficulty involved in the requirement that a party disclose this fact before introducing evidence upon the issues. But in the case of proof of general character, there is a practical difficulty which would prevent a successful operation of the New York bill. It is easy, enough to disclose the record of one having

${ }_{99} 227$ N.Y. 94, 98-99, I24 N.E. I26, I28 (r9rg). See also, Vause v. U.S., 53 F. (2d) 346, 35I (C.C.A. $2 d$ r93I). Compare Labrie v. Midwood, 273 Mass. 578, I74 N.E. 2 I4 (I93I). 
been convicted of a felony, as the witness would ordinarily prefer telling this fact for the party who calls him, rather than admit it upon crossexamination. It is then more in the nature of sustaining than impeaching evidence. But upon the issue of general credit, it might be impossible to show bad reputation by the witness himself, and it is not feasible to call other witnesses to testify about it before examining the witness. The result is that, upon the subject of proof of reputation for truth and veracity, the effect of the New York proposal is practically to deny it. Assuming that the bad reputation of a witness is shown by other witnesses, it would be most unusual psychologically, to be able at that time to obtain helpful testimony from the witness. This phase of the bill thus results in no more than to permit the party who produces a witness to disclose facts known by the witness about his own character which the witness will admit. Only in event that the bad reputation of the witness was not known at the time of examining the witness can it be shown after examination. The proposed New York act has the salutary objective of requiring a party who knows the faults of his witness to disclose them before he knows what his testimony will be, rather than wait and disclose them only if the witness turns out to be against him. The only question is its practicality in opening the way to full impeachment.

\section{COMPLETE ABROGATION OF THE COMMON LAW RULE}

Whether the New York proposal has gone far enough in the renewal of the inhibition of the common law rule is questionable. The intent of the sponsors has undoubtedly been that it would do more than its functional operation may prove possible. They have assumed the ability to impeach successfully the general credit of the witness by the party who calls him, before he testifies. As has been pointed out, the use of bad character evidence, except as the witness makes his own disclosure, is practically ruled out as a usable impeachment device. This raises the question whether the legislation should provide generally that a party may impeach his own witness in the same manner and under the same circumstances as he may impeach the witness of his adversary. Mr. Wigmore favors the complete abolition of the common law rule. ${ }^{\text {I0o }}$ The report of the Committee of the Commonwealth Fund in 1927 , commenting upon the rule, stated that "The rule prohibiting impeachment of one's own witness .... has no shadow of good sense in any of its parts." "rox The gist of the theory favoring the limitation imposed by the New York plan is the assumed unfair-

${ }^{100} 2$ Wigmore, op. cit. supra note 1 , at $\$ \S 896-904$.

ror Report of the Committee of the Commonwealth Fund, The Law of Evidence-Some Proposals for its Reform, xvi, n. I (I927). 
ness of counsel when he presents a witness, knowing his reputation is bad, and then fails to disclose it if he gives favorable testimony. This would be the result of an open door rule, and yet would allow the party to discredit the witness if his testimony were unfavorable. The New York limitation penalizes party and counsel, by precluding impeachment when disclosure is not first made. In doing so, has it impaired just decisions of causes in our courts by preventing the fact of the witness' character from being known when the party who calls the witness is then the only one who would make the disclosure of bad character? It should be observed that the impeachment rule at common law has not prevented parties from presenting objectionable witnesses and accepting their beneficial testimony without disclosing their bad character. Parties have only had to gamble on the chances that the testimony would be favorable. The rule has only prevented showing bad character when the testimony is destructive. Usually the opponent adequately takes care of attacking the character of the witness when the testimony is beneficial if the occasion calls for it. If the party were allowed to impeach his own witness when he has given destructive testimony it would merely give him the same right which the opponent has when the testimony is helpful. The New York bill emphasizes the good faith element by requiring the party himself to disclose the bad character of his own witness whether his testimony be favorable or not, if he wishes to raise the character issue. May an opposite position be justified? This brings us again to Bentham's idea that good men may sometimes falsify and bad men may generally tell the truth, and that there is no fixed category into which all mankind can be placed under all circumstances and at all times. Is it not an incongruous situation which is apparently required for a party to be fair under the New York hypothesis, namely that he expose the bad reputation of his witness after he has given favorable testimony which the party producing him believes is the truth? It is very much questioned that a party should be compelled to be the one to produce evidence upon the character of his own witness, when the technical position in which he is placed is considered, and it can hardly be said that it is unfair for him not to do so. Furthermore, the opponent might find it indiscreet to attack the character of a witness in situations in which he was obviously telling the facts honestly. The point is simply that there are occasions in which a party might be willing to rely upon the testimony of a generally undesirable witness, if his testimony were true, without exposing his bad character, but if the witness gave false testimony he would feel that he ought to expose it. ${ }^{\text {Io2 }}$

${ }^{03}$ Starkie, Evidence 217 (1824). 
From another angle, these same factors would tend to curb abuse of this type of impeachment by a party of his own witness. The ostensible impropriety of a party in calling a witness and impeaching him if he testified against him, would naturally cause attorneys to be hesitant in using this method of impeachment. If counsel abused the privilege of using character testimony, he would pay the price with the jury, who might resent too much of such procedure. This is true in the case of the use of general character evidence against the witness of. an adversary, an $a$ fortiori in the case of a party's own witness. Excessive use of impeachment would be checkmated by its own dangers.

The proposed New York act represents such an advanced step in legislation upon the subject, and is so well supported by good propriety, that it is to be strongly commended. It is surely preferable to all former acts, but hardly accomplishes all that is desired. It apparently assumes that it has opened the door of impeachment wider than it in fact has. It also involves distinctions, and opens the way to fact determinations (such as whether or not the party knew the witness' character before he testified), which may permit unnecessary appeals and reversals. A more simple form of legislation, which would dispose of the entire problem, is suggested as follows:

No party shall be precluded from impeaching a witness because the witness is his own.

This would eliminate all confusion, and the troublesome distinctions which give rise to litigation upon the subject, where statutes but partly remove the inhibition. The restraint upon impeachment of a party's own witness has burdened the courts from the Sixteenth Century to the present day. The courts have shown their dislike for the rule by a gradual process of distinction and qualification which is characteristic of the existence of an unwise rule of law. It is doubtful that the rule could have endured long, if it were not for the ingenuity of both courts and lawyers, in escaping its rigid application wherever possible. The piecemeal process of partial elimination of a rule fundamentally unsound but promulgates the principle as an heirloom of past centuries. While commending the progress of legislation, and particularly the advancement of the New York proposal, it is believed that better results would be obtained by complete abolition of the rule. 